\title{
Corrigendum: Dual NDP52 Function in Persistent CSFV Infection
}

\section{Shuangqi Fan ${ }^{\dagger}$ Keke $\mathrm{Wu}^{\dagger}$, Chaowei Luo, Xin Li, Mengpo Zhao, Dan Song, Shengming Ma, Erpeng Zhu, Yuming Chen, Hongxing Ding, Lin Yi, Jun Li, Mingqiu Zhao* and Jinding Chen*}

College of Veterinary Medicine, South China Agricultural University, Guangzhou, China

Keywords: classical swine fever virus, NDP52, ubiquitination, CD63, NF-кB

\section{OPEN ACCESS}

Edited and reviewed by:

Zhengli Shi,

Chinese Academy of Sciences, China

*Correspondence:

Mingqiu Zhao

zmingqiu@scau.edu.cn

Jinding Chen

jdchen@scau.edu.cn

tThese authors have contributed equally to this work

Specialty section: This article was submitted to

Virology,

a section of the journal

Frontiers in Microbiology

Received: 27 February 2021

Accepted: 11 March 2021

Published: 12 April 2021

Citation:

Fan S, Wu K, Luo C, Li X, Zhao M, Song D, Ma S, Zhu E, Chen Y, Ding $H$,

Yi L, Li J, Zhao M and Chen J (2021)

Corrigendum: Dual NDP52 Function in

Persistent CSFV Infection

Front. Microbiol. 12:673468

doi: 10.3389/fmicb.2021.673468

\section{A Corrigendum on}

Dual NDP52 Function in Persistent CSFV Infection

by Fan, S., Wu, K., Luo, C., Li, X., Zhao, M., Song, D., et al. (2020). Front. Microbiol. 10:2962. doi: 10.3389/fmicb.2019.02962

In the original article, there was an error. ${ }^{* *}$ In paragraph 5 of the introduction, NDP52 is typed as NDP5: "In Salmonella typhimurium infection, NDP5 promotes pathogen-containing autophagosome maturation and independently regulates targeting of bacteria to mature autophagosomes (Verlhac et al., 2015a)"**.

A correction has been made to ${ }^{* *}$ the introduction ${ }^{* *},{ }^{* *}$ Paragraph $5^{* *}$ :

** In Salmonella typhimurium infection, NDP52 promotes pathogen-containing autophagosome maturation and independently regulates targeting of bacteria to mature autophagosomes (Verlhac et al., 2015a)**.

The authors apologize for this error and state that this does not change the scientific conclusions of the article in any way. The original article has been updated.

\section{REFERENCES}

Verlhac, P., Grégoire, I. P., Azocar, O., Petkova, D. S., Baguet, J., Viret, C., et al. (2015a). Autophagy receptor NDP52 regulates pathogen-containing autophagosome maturation. Cell Host Microbe 17, 515-525. doi: 10.1016/j.chom.2015.02.008

Copyright (c) 2021 Fan, Wu, Luo, Li, Zhao, Song, Ma, Zhu, Chen, Ding, Yi, Li, Zhao and Chen. This is an open-access article distributed under the terms of the Creative Commons Attribution License (CC BY). The use, distribution or reproduction in other forums is permitted, provided the original author(s) and the copyright owner(s) are credited and that the original publication in this journal is cited, in accordance with accepted academic practice. No use, distribution or reproduction is permitted which does not comply with these terms. 